\title{
Chinese Art within Thai Temples in Malaysia: The Disappearance of Thai Art
}

\author{
Punya Tepsing ${ }^{1}$ \\ ${ }^{1}$ Faculty of Liberal Arts, Prince of Songkla University, Songkhla, Thailand \\ Correspondence: Punya Tepsing, Faculty of Liberal Arts, Prince of Songkla University, Songkhla 90112, \\ Thailand. Tel: 66-83-14-6692. E-mail: punya.t@psu.ac.th
}

Received: August 12, 2014

Accepted: December 2, 2014 Online Published: April 2, 2015

doi:10.5539/ass.v11n9p43

URL: http://dx.doi.org/10.5539/ass.v11n9p43

\begin{abstract}
The identity of Thai temples in Malaysia is disappearing, as the temples display more Chinese art than Thai. Thus, this research aims to investigate the patterns in Chinese art and the conditions that support the appearance of Chinese art within Thai temples. Chinese art appears within these temples in their sculptures of Buddha, pavilions, and walls. The conditions supporting the appearance of Chinese art include 1) the need for funds to construct new temples; 2) the abilities of pastors who can speak Chinese and English and are interested in art from various countries; and 3) the eastern coast of Malaysia being a place where many people of Chinese descent settled. Chinese people were not able to purchase land easily due to state laws; thus, they had to use Thai temples as places to preserve their identity by constructing Chinese art within the temple.
\end{abstract}

Keywords: Chinese art, Thai temple, Malaysia, disappearance

\section{Introduction}

Chinese culture has been found in Malaysia since the $15^{\text {th }}$ century (Khin \& Huat, 2005). This appearance has been seen in everyday life through Malaysia's faith, art, architecture, clothing, and food. Chinese culture has also influenced Thai temples. Tepsing (2011) found that a Thai temple in Penang Island was influenced by Chinese art because the island is surrounded by Chinese communities. The art of Thai temples is a mixture of Thai art and Chinese art. However, Chinese art frequently appears in Thai temples, when situated in places where the Chinese community is in the minority, especially close to the Thai border in Northern Malaysia, where many Thais settled. There are more Chinese temples than Thai temples in this area. Symbols that refer to Thai temples include Buddhist ceremonies by Thai priests and symbols indicating that the temple was constructed in a Theravada pattern. Funsion (2010) suggested that ethnic groups in southern Thailand and northern Malaysia were related to each other, especially in Kelantan State, Malaysia, where many Thais settled in. However, many Thai temples contain Chinese influences. This suggestion has been supported by a study by Ismail (1994) finding that Siamese temples typically had a statue of Quan Yin situated within them. Although belief in Quan Yin is limited amongst Thais, Thai temples had to have these statues because the temples needed the support of the Chinese community.

Accordingly, the research question is to determine how Chinese art began to appear in Thai temples and what conditions influenced its appearance. This study was based on the concepts of cultural diffusion and acculturation. We use Wat (Temple) Phothikyan Phutthathum as a case study because it has been decorated by Chinese art. The temple is located in Balai village, Bachok district, Kelantan State, Malaysia, and is 25 kilometres away from Kota Bharu city. This Thai temple was abandoned for a long time by the Siamese community. This area is settlement of Malaysian Siamese or Malaysian of Thai ethnicity. The name of the district - "Bachok"- is assumed to be the name of a Chinese silk and spice trader who anchored his boat in this area. Another assumption behind the name Bachok came from the Siamese person who named this area. Bachok came from a village that was full of "ton chak" trees, which was transformed into Malay as Bachok (Bachok: 2013). Both assumptions reflect the notion that this area was originally settled by people of Siamese descent. While Malaysians of Chinese descent mostly live in urban areas, some who also contain Siamese descent live in the countryside. This assumption supports Seong's study (2008), which stated that the Chinese in Kelantan State lived more rural lifestyles than the other ethnic groups. Thus, they and people of Siamese descent lived together because they were both the minority in Kelantan State, in which the majority of people are Muslim. 
Kelantan is the Malaysian state in which Siamese individuals are the most prevalent, and they still maintain their own Thai culture strongly. They adhere to Theravada Buddhism and have built many beautiful temples (Sarimah, 2004). Balaiwanaram temple, the former name of Phothikyan Phutthathum temple, was constructed about 200 years ago by Siamese and Chinese people in Balai village. They dedicated 6 acres of land to constructing the temple and invited Phra Bok as a pastor. Later, when Phra Bok died, the villagers invited other monks to Balai village, in order to maintain the temple. Afterwards, the temple was abandoned again until Phra (Monk) Phochai came to Kelantan from Thailand. He had seen the temple's lack of development; thus, he and the villagers discussed renovating the temple and renamed the temple to Wat (Temple) Phothikyan Phutthathum.

\section{Objectives}

1. Study the patterns of Chinese art within Thai temples.

2. Study the conditions that supported the appearance of Chinese art within Thai temples.

\section{Methodology}

Data were collected from literature reviews, observation of the temple, and in-depth interviews of stakeholders based on a conceptual framework. The data collection approach was as follows:

\section{Observation and note-taking of the temple's landscape}

2. In-depth interviews with stakeholders, who were classified into 2 groups: 1) a total of 10 temple committee members, liaisons, and monks who were selected using a purposive samples approach and 2) five visitors who were selected by an accidental samples approach

3. The collected data were analyzed by content analysis, and the results were presented using a descriptive approach.

\section{Results}

\subsection{Chinese Art within a Thai Temple}

The Chinese art at Wat Phothikyan Phutthathum is based on the actions of the Buddha. The statue stands in a straight pattern on a lotus base, with its left hands holding a lotus, the right palm flared out, a striped robes, a moon faces with coiling, and a small point between its eyebrows. The Buddha statue is constructed out of mortar and painted white. Under the lotus base is a room that is decorated with many Buddhist drawings. Locals call this statue Phra Amitabha (Figure 1) Though Wat Phothikyan is a Thai temple, the focus of this temple is the Chinese art within the temple. The Phra Amitabha is a Buddha of the Sukhawadee doctrine (Lotus doctrine). It is believed that his land is in the west; thus, so both the temple and the statue are set in the west of Balai village.

The construction of the Buddha by mixing Chinese art with what Thai art has in common. The Phra Amitabha was constructed because Siamese people mostly have faith in the next life. On a lotus base, the stairs on both sides allow one to walk around the Phra Amitabha statue. There are censers on the ground level and upstairs. A petal of the lotus blossom that is focused upon is a symbol that indicates the Sukhawadee doctrine. In front of the Buddha is a wide yard. The temple also sets a spotlight on the Buddha at night. Constructing a large outdoor Buddha is not only for faith, but also to meet the tourism demands of Balai village

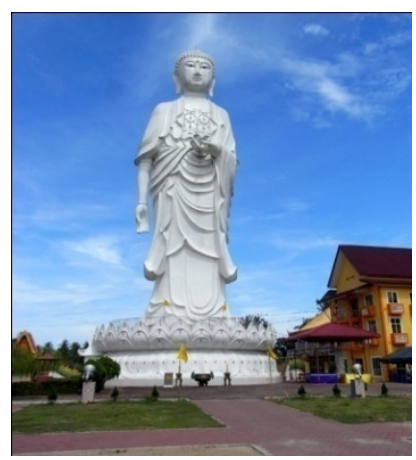

Figure 1.

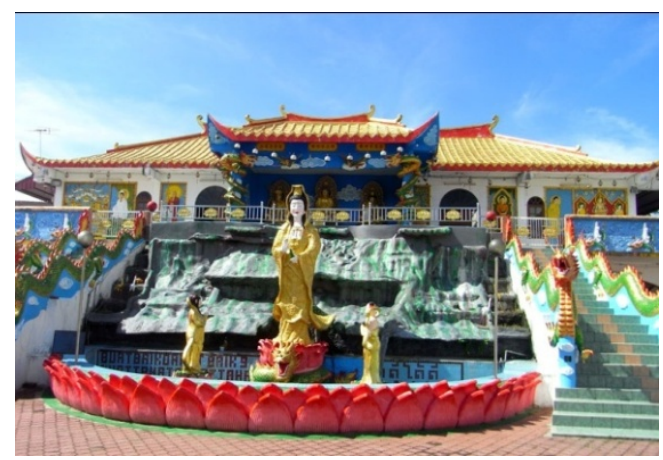

Figure 2. 
The chapel and the monks' residence are in the same two-floor building, which is decorated by Chinese art. The second floor is a place for worshipping 3 sacred Chinese Buddhas, including Avalokitesvara Ksitigarbha (on the left), Phrasrisakayamuni (center), and Avalokitesvara Bodhisattvas or Kuan Yin (on the right). Nevertheless, this chapel is also used as a multipurpose building. It is not only for Buddhist ceremonies, but also for preaching, welcoming visitors, cooking food, and more. The stairs at the front of building are decorated with a stone garden, a small pond, and a small statue of the Guan Yin. The handrails are decorated with a sculpture of a dragon mixed with a naga. This stair pattern has often been seen in Thai archaeological sites and temples and is based on the Thai belief that the naga stairs are a pathway to heaven. The naga's head and body are similar to those of a Chinese dragon. The wall is decorated with stucco, and the colourfully painted background around the Chinese Buddha, or Poi Sian god, is based on Chinese folklore. On another side of the wall is a painting of the Buddha sitting in meditation. This reflects the traditional Chinese belief that there are many Buddhas. The balustrade has been placed with the lotus. A fence decorated with a drawing of Kuan Yin stands on a dragon's head and a cloud. An interior design like this seems to prefer the Chinese patterns to the Thai and seems to harmonize Chinese and Siamese architecture. This has resulted in Thai art looking inferior, oppressed, or driven out of the Siamese or Thai identity.

In the temple is a Chinese octagonal bell tower. The roof is laid with dragon-shaped roof tiles. Each pillar has a dragon wrapped around the pillar, with Kuan Yin standing on each dragon head. Between each pillar is a sculpture of a phoenix attacking a dragon (Figure 3). A sculpture of Guan Yin riding the dragon is also found in this temple. There is a Chinese-style pavilion located in front of the language and Buddhism school. The pavilion is mostly used by students of the school to relax. The design of the language school is simple, and has a familiar, single-floor, Thai pavilion in a rectangle shape, with a gabled canopy in each roof corner (Figure 4). This Thai pavilion is located in the front, near the monks' residence. The Thai pavilion is decorated with something to present the mythical concepts on the roof, which reflects Thai architecture (Sthapitanonda and Mertens, 2005). The pediment of the Thai pavilion is decorated with a Thammachak sculpture above a Thai trim panel. The combination of both Chinese and Thai pavilions in this temple reflects the community's culture, which has two perspectives. One was used in order to maintain identity, and the other was used to raise funds to construct the building.

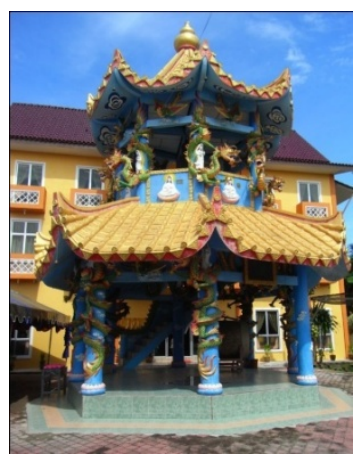

Figure 3.

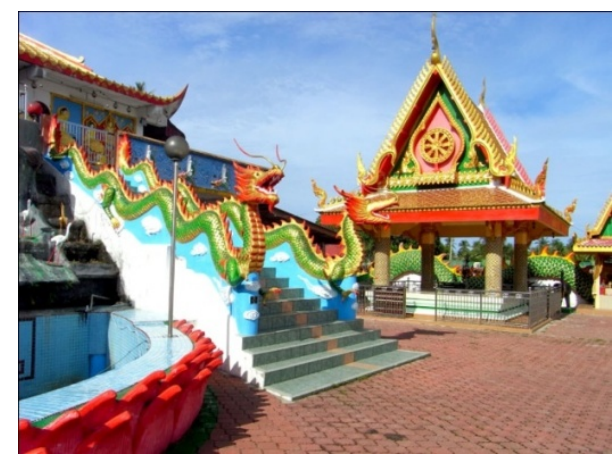

Figure 4.

Near the Chinese pavilion is the Chinese Buddha shrine. This place has an open space, which allows villagers to worship or do activities anytime. There are three Buddha sculptures in the shrine: a statue of Maitreya, a fat Buddha with a smiling face, and two Arhats or Lohons, one carrying banana leaves and another carrying a staff and gold (Figure 5). People who worship these three Buddhas are believed to receive great fortune. In front of the shrine is the head of a Thai-style Buddha, which is placed at a lower position than the Chinese Buddha. On the backdrop of Buddha is a painting of clouds. The front pillar is decorated with a dragon. There are a donation cabinet, a candle, and a joss stick pot in shrine. This reflects the influence of the Chinese art that dominates this Thai temple. Other parts of the temple seem to be superimposed with Chinese traditions. As one of the villagers said, "The Chinese donated money to build the temple. They have authorized [the temple] to create anything" they want.

At the back of temple, outside the wall, is a Chinese-style building for praying and performing spiritual rituals. It has a niche that contain the ashes and labels of Chinese ancestors. On the other side is a house-shape monument containing the ashes of wealthy individuals. These small saloons require rent to be paid. The saloon's pattern is the same as the saloons for villagers, with a small box containing the ashes and labels of ancestors (Figure 6). 
The art behind the temple also reflected Chinese traditions, and was dominated by the Chinese. The land behind the temple was originally dominated by outlaws, as the Siamese did not have any authority in this area. The Chinese had raised money to buy the land from the villagers, in order to expand the temple's area and construct a cemetery. The Chinese used the Thai temple as a channel for constructing a spiritual area because Kelantan law did not allow the Chinese to buy the land from Malaysians. The Chinese only could buy the land from Siamese or Chinese individuals.

Phothikyan Temple does not have a lotus that contains ashes or bones, due to local Thai tradition. Generally, Thai temples are likely to construct these lotuses similarly to a small pagoda and bury them in the basement. If Balai wanted to set up a jar for ashes within the temple, they would do so according to Chinese practice, which reflects that some of Thai culture has been assimilated into Chinese culture. The villagers are in a situation of servitude because most of them are quite poor. They had to rely on the Chinese to do many activities for the community. Therefore, the Thai art at Phothikyan Temple has deteriorated, and almost lost its Thai identity.

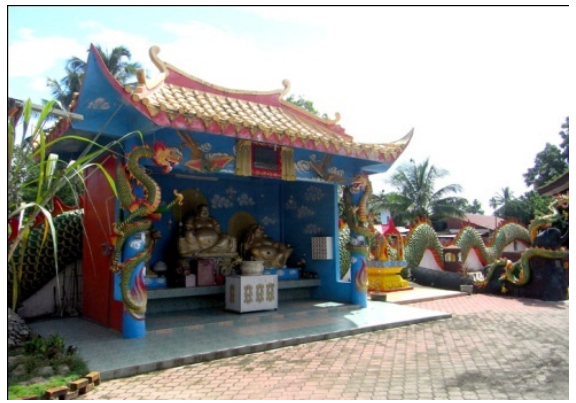

Figure 5

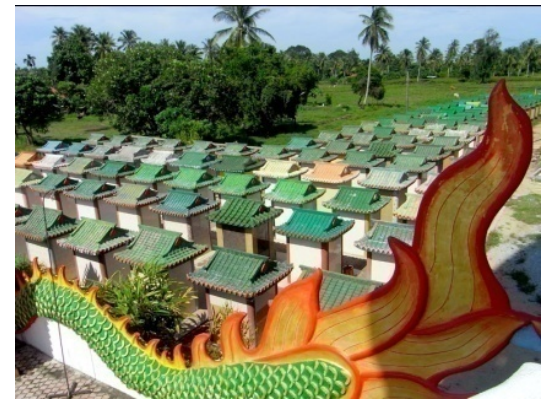

Figure 6

The outstanding point of Phothikyan Temple is the wall, which features dragon-coiled tendrils. The dragon's head is at the door, and the body is whipped until the tail becomes close to each side. It looks like there are 2 dragons on the wall, (Figure 7). One of the dragons is 1,973 feet long, and has the longest dragon wall in Malaysia. On this wall, one side of the dragon's body looks like it is sinking into the ground. This was the idea of a former pastor, after buying the land from the villagers to expand the temple's area. He constructed the dragon by burrowing its body underground and revealing the other side of the dragon at the end of the new temple area, (Figure 8).

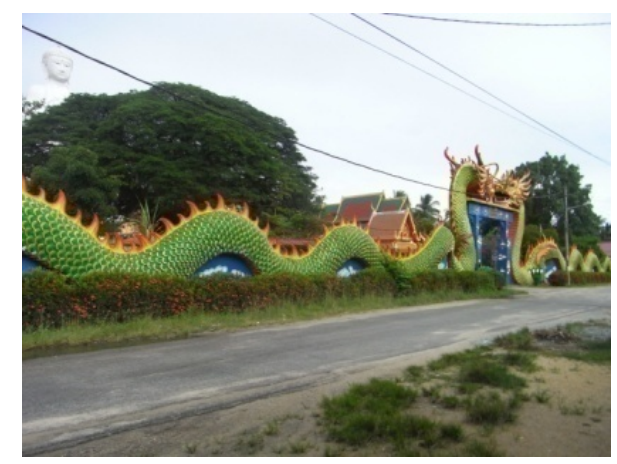

Figure 7

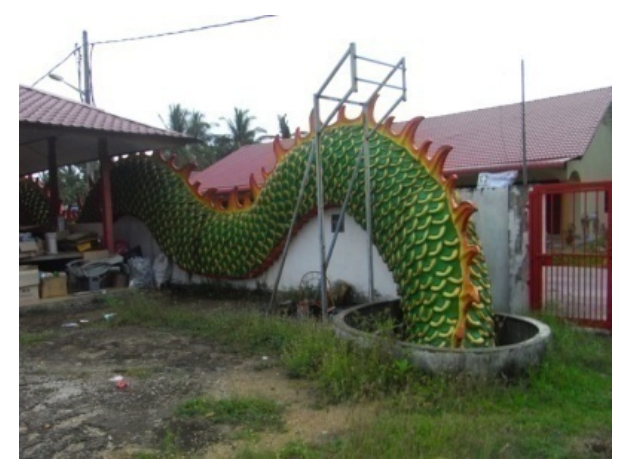

Figure 8

\subsection{Conditions Supporting the Appearance of Chinese Art in the Thai Temple}

The results found that Phothikyan Temple has more Chinese art than Thai art for three main reasons. The first is its pastor's abilities and leadership. Phothikyan Temple was originally an abandoned temple until Phra Photichai, a monk from Thailand, came to Balai village. He developed and renovated this abandoned temple. Funding was a main obstacle to developing the temple, and he was in charge of multiple duties at the same time. This caused the temple to develop slowly. The second reasons, Phra Photichai could speak Chinese and some English, which 
helped him to cooperate with investors and foreign visitors to develop the temple. He also liked travelling to see Buddhist art in many other countries, which he adapted to Phothikyan Temple. His capabilities helped the temple to raise construction funds rapidly. As a villager said:

'He had travelled to Taiwan and China to see ideas for temple construction. A large Buddha sculpture was constructed based on his ideas. Chinese people gave him the money to construct the temple. If you wanted more money, you would construct [the temple] in the Chinese pattern'. (Thepsirin, 2011)

This quote reflects that the pastor led the use of Chinese art without fear of accusations from villagers. He not only constructed the temple as a spiritual place for villagers, but also wanted this place to become a new tourism attraction in the area. He thought that Chinese art would attract wealthy Chinese to participate in the temple's activities. The large Buddha was constructed as the outstanding feature of this temple to attract visitors and generate income for the community.

In comparison, a pastor of Machimmaram Temple used superstition to spread belief and faith in Buddhism among the villagers and ask for donations to construct a large Buddha. The pastor of Phothikyan Temple, meanwhile, created faith by using advertising and public relations approaches, as well as his energetic desire to achieve his will. As one of the senior monks said:

'He was incredible. He used to hike from Kelantan to Singapore. He took two months to go to Singapore and two months to return to Kelantan. He walked 30-40 kilometres a day. His practices created faith for the villagers. People started to know Phothikyan Temple more, and it was easy to ask for donations'. (Mahasomsak, 2011)

This approach was designed to publish a project in both Malaysia and Singapore to construct a large Buddha, whereas Matchimaram Temple's pastor used a passive strategy by only waiting for donations from within the temple. The Balai people praised Phra Photichai for his leadership skills. He developed both the temple and community. Phra Photichai resigned from being the pastor and returned to Thailand, although the villagers still remember his practices as a pastor.

The Thirst reason is based on historical evidence, Chinese people are mostly concentrated in the eastern states of Malaysia because their ancestors largely came ashore on the eastern part of the Malay Peninsula before moving to the other parts of Malaysia, especially Terengganu, where many Chinese people live. However, Kelantan's laws are quite strict against minorities and immigrants, especially for purchasing land among the Siamese and Chinese minorities. The close relationship between the Thai and Chinese cultures resulted in the assimilation of their cultures, which was based on 3 factors: 1) the Chinese population had more economic power than Thais; 2) the state laws treated minorities strictly; and 3) there is no Chinese Buddhist temple in Kelantan State.

In Kelantan State, both Siamese and Chinese descendants have been classified as minorities, but the Malaysian government gave more rights to the Siamese than the Chinese. By the way, the Chinese have economic control over the local population. They are mostly business owners, investors, or philosophers. Even though they had high incomes, they could not buy land, due to the state's laws. Thus, they have had to ask for donations of land from locals or Siamese people to use for religious activity. As one farmer said:

Originally, the Siamese built the temple. Siamese never leave Buddhism, but they were mostly quite poor. They had only their faith, but not money (Thepsirin, 2011)

While Siamese individuals were convincing the Chinese to support temple construction, the Chinese also wanted to build merit at the same time. Both requirements were negotiated, which resulted in the Thai temple holding the accumulated wealth of Chinese art. The restoration of the temple took place, due to the need of the Chinese to make pilgrimages, which caused the Thai identity of the temple to be reduced. Foucault (2007) said that every culture in the world has created ideological spaces called heterotopias, which are different depending on cultural factors. Originally, this space was a heterotopia of deviation, which is a deviational space that is isolated from societal norms. The Thai temple was first constructed from the mental perspective of Siamese individuals, but later the temple became constructed for the Chinese people. This caused the cultural assimilation between the Thai and Chinese cultures in the temple.

Phothikyan Temple is popular among the Chinese population because there is no Chinese Buddhist temple in Kelantan State. They have only had spiritual houses to worship the Chinese Buddha. Therefore, Chinese people used Thai temples to create their identity through the art of the temple. They used Thai temples as predecessors for purchasing land from the Siamese. One of the villagers said that:

'Kelantan did not have a Chinese temple. The Chinese thus relied on the Thai temple, in order to carry out their activities. They donated a lot to the Thai temple' (Wanwilai, 2011) 
The Chinese population bought the land behind Phothikyan Temple from the villagers to build a cemetery that was decorated by Chinese art, in order to store their ancestor's bones that had been buried. Now, the Chinese population uses cremation in their funerals and stores the ashes in the small pavilion, which is decorated by Chinese art. This reflects a blending of Thai culture into Chinese culture that not only appears through the arts, but also through the merging of spiritual practices.

In addition to the absence of a Chinese temple in Kelantan State, the state has also issued traditional laws based on Islamic practices. It has used these acts to rule over people from other religions who have not encouraged Muslims to convert to other religions. The State Council established an Islamic committee to serve the interests of Muslims. If some Muslims converted into Buddhists, the council would react immediately. Meanwhile, Siamese monks did not try to obtain help from Muslims to construct the temple, and did not persuade Muslims to be Buddhists. This phenomenon resulted in the close relationship between the Siamese and Chinese populations. In addition, the Thai temple has been watched over by Sultan of Kelantan. Thus, Muslim officers rarely intruded upon activities within the temple. The Thai temple is free from any state control. As a local said:

'The Muslims were not likely to intrude upon the temple. In the temple, there were only Siamese and Chinese people. If the pavilion was designed with Chinese art, it meant that the Chinese were the patrons of the temple. If the pavilion was designed using Siamese art, it meant that the Siamese were the patrons of the temple'. (Chantaro, 2011)

\section{Discussion}

Thai temples in Malaysia have been influenced by the Chinese, due to the Chinese cultural diffusion into the Malay Peninsula. Thai art and culture, which were dislodged from temples, reflected the weakness of Thai culture, which was far from its cultural core. Boas (1966) suggested that, if a culture extends into other areas, it would be marginalized by other cultures that were stronger, which would result in cultural acculturation. The Chinese have more economic power than the Siamese, and the Siamese also needed economic support from the Chinese. This resulted in the cultural accumulation between Chinese and Thai culture in the temple. In addition, both the Siamese and Chinese populations also used the temple as a space to create a network among the minorities. This result has conformed to the findings of Horstmann (2004) that Kelantan Thais are balance their alliances between the rural and urban Chinese to cope with economic problems under growing Islamzation and Kataoka's study (2012), which states that Buddhist can absorb the attendents of Chinese temples into the category of Buddhism to maintain the uniform image of Thai Buddhism. Thai Buddhism in Malaysia, as a minority religion, uses various approaches to negotiate for equality within society. One approach has been to create its own network with others, while also creating a sense of citizenship in the state at the same time.

People of Chinese descent are the largest immigrant group in Malaysia and have built the most temples (Khin \& Huat, 2005). Phothikyan Temple reflects how Chinese-Malaysians have interacted with Siamese people, in order to find their collective spiritual anchor. Meanwhile, they also visit the temple to recreate the fineness of Buddhist art. The interaction among different cultures within Thai temples in Malaysia has been significant for the pursuit of spirituality and tourism in different ways:

\subsection{Interaction between the Siamese and Chinese Cultures Caused by a Collective Reliance on Life and Death}

The Thai temple has been considered to be a symbol of cultural accumulation between the Thai and Chinese cultures. The blending of arts in the Thai temple is reflected in the interactions between different cultures of people who are considered to be minorities in Kelantan State. This resulted in the wonder of visitors who have found the Thai temple full of Chinese Buddhas. Such interactions have occurred because of the capitalist approach. It is rational for Siamese people to ask for help from Chinese people to construct the temple, and the Chinese would accept requests or not, depending on the negotiations. As Chantaro (2011) who is a liaison said, 'Most of the Chinese are rich. They would donate money to build the temple. By the way, they will ask Thai people to build the temple with Chinese art. They would be proud if there was a Chinese Buddha within the temple'.

The study shows that Chinese immigrants in Malaysia have tried to adapt themselves to the local culture, but they would not abandon their traditional practices. This result has been supported by Beng's study (2010), which states that Chinese immigrants can live and adapt to different regional and socio-cultural environments. This is also supported by Mason's study (2009), which found that Chinese people have been trying to preserve their own culture and wanted to spread their culture within Malay society at the same time. A Buddha of Amitthapa is evidence of the success of the Chinese people in constructing Chinese art within the Thai temple. This not only meets the funding needs of the temple to develop the temple, but also meet the Chinese demand to have a spiritual, sacred place. Meanwhile, Siamese people have considered the Buddha of Amitthapa to be a tourist 
attraction, more than for serving spiritual purposes, because most Siamese people worship Phrasrisakayamuni. This result is supported by Johnson (2011), who found that images of Chinese god and Thai style Buddha associate the community with local process. When considering the interactions behind the large standing Buddha as collective, Siamese people would relate to the Amitthapa as a Buddha that is supported by the Chinese. They would not focus on the doctrines about death as much. On the other hand, Chinese people consider the Amitthapa to be an important Buddha in the next world. They want to stay in heaven with the Amitthapa after death. This belief has resulted in the creation and meticulous decorating of family cinerary urns.

\subsection{Interaction between Thai and Chinese Cultures in Thai Temple, from a Tourism Perspective}

The outstanding art in Phothikyan Temple convinces many tourists to visit. Visitors come from various countries, such as Thailand, China, or even Muslim countries and India. This place has become a place of learning for ethnic interactions and integration (Muhamat, 2012). This outstanding place has become a wonder to the Muslims, as Thepsirin (2011) said that 'Muslims have investigated the temple because they wonder how we raised funds, and what Buddhism is about'. People not only wonder about the beauty of the temple, but about the concepts of Buddhism. This place has then become a cross-cultural learning place for Muslims and visitors from different cultures.

Phothikyan Temple is a tourist attraction because of the cultural tourism policies of Kelantan State, which has used the Thai temple as a beautiful place to attract visitors. The Thai temple in Kelantan has large Buddhas performing different actions, including sitting, reclining, walking, and standing. Similarly, a walking-action Buddha sculpture is located at Pikulthong Temple, a reclining-action Buddha sculpture is located at Potivihan Temple, a sitting-action Buddha sculpture is located at Machimmaram Temple in Tumpat District, and a standing-action Buddha sculpture is located at Phothikyan Temple. The latter two Buddhas were constructed in Chinese patterns. Phothikyan Temple contains three outstanding spots: 1) the tallest Buddha sculpture, 2) the longest Dragon wall, and 3) the most beautiful building in the temple. As Srisuwan said (2011), 'now this temple is a major tourist attraction for the state. Visitors from Taiwan, Singapore, Japan, and Western countries have come to visit. The longest dragon wall, the tallest Buddha sculpture, and the most beautiful shrine are here'.

Tourism has resulted in the exchanging of knowledge, language, and culture between the locals and visitors. Visitors have come to learn about the local culture, which is integrated with the Thai and Chinese cultures. This could help Muslims to accept the Buddhist identity more readily. The Thai art is mediated by the relationship between various peoples who have come from different cultures. Isa (2012) stated that art has its own power; it can be easy to understand, change attitudes, beliefs, values, and behaviour, and create understanding in multicultural areas like Kelantan State. The creation of Chinese art within the Thai temple reflects that a Thai temple beyond the area of Thailand is easily changed by other cultures. The Siamese population did not have a sufficiently high economic status to maintain the temple, which provided the chance for the Chinese population to play roles in the Siamese temple, such as for religious purposes or tourism.

\section{Conclusion}

From this study, we found that Thai temples in Malaysia were transformed in modern society because the Chinese Malaysians were supported. Although the Chinese were a minority group and migrated to the Malayu peninsula a long time ago, there are now many Chinese Buddhists living in the Muslim society, under many Muslim rules and traditions. However, the Chinese in Malaysia accepted modernization and used a modern style, mixed with Thai and Chinese architecture to develop Thai temples, such as in the style of a central sanctuary in a Thai temple, and they also have developed Thai temples to be places of religious and nostalgic tourism, which brings many people from Western and neighboring countries. Local people also come to visit to pray, donate, and take a rest, raising the income of Thai temples.

However, developing Thai temples to be open for tourism and developing a mixed architecture between Thai and Chinese styles have very complicated issues because some committees of the Thai temples do not agree with these changes. Some committees are conservative and would like to transform nothing about Thai temples or they do not want the Thai temples to be places of tourism, so they have thought about how to change the minds of Chinese investors to think about a Siamese identity (Malaysian Siamese is a term commonly used to refer to Malaysians of Thai ethnicity). The Siamese are also minority group like the Chinese, but the Chinese are in control of the economic system and have influence in the Thai temples because they have capital invested in and donated to Thai temple. As such, they now want the Thai temple to look like a Chinese temple and do not care what the Thais and Siamese think. Kang and Feng (2013) state that modern Chinese society is very complicated, and many Chinese think about the economy more than the old traditions and culture. 
So, whether the Thai-style architecture remains a part of the Thai temple depends on the awareness of the Siamese, and they should have a greater awareness and protect their Thai art and architecture. At the same time, Chinese investors should change their minds and not look only at their benefit; they should also respect others, especially the art, culture, traditions, and architectural styles of other religions and/or nationalities. Although, the Chinese and Siamese are a minority, living in a Muslim society, such as Alwi's (2010), it is suggested that in Malaysia there is good interaction between Buddhists and Muslims in Kampung Tendong, Pasir Mas, Kelantan. The important thing is how to stay together in mix culture and mixed tradition places which is essential to the policy-makers to develop a better pattern of inter-racial interaction

So, when art changes to a new type of art or when art appears in another culture or tradition, it is because the culture is spread and driven by geography and the long history of the Malayu peninsula. King Rama 5 of Thailand gave the land in Kelantan, Trengganu and many lands in the north of Malaysia to the British. In these parts of the land many Thais Buddhist people remain. After Thais in these lands changed their nationalities to Malaysian, the Malaysians called them Siamese, and then they are transformed from mostly Thai Buddhist people in Thailand to a minority in Malaysia. At the same time, many Chinese Buddhist have migrated to Malaysia include the northern lands, where the Chinese have economic power because they are traders and donate money to Thai temples because they are also Buddhist. This is why we can see mixed art and architecture between the Chinese and Siamese in the Thai temples.

From this study, researchers can conclude three reasons why the art of the Thai temples is transformed to a mixed architecture: first, Thai art is not under the control of the Thai government and the Thai government is not concerned as much with this matter, so it is difficult to maintain Thai culture in Malaysia. Secondly, Chinese art came to Thai temples in north Malaysia, closely bordered to Thailand, which shows the weakness of central Thai culture. This also means that the central Thai government never set up the policy to maintain Thai culture outside of Thailand, so, Singaporeans and Malaysians who are faithful to Buddhist teachings, donated to and invested in the temple, and after that, they had more bargaining power to manage the Thai temples. This issue is making it difficult for the Siamese to negotiate and protect Thai art and architecture. Third, money is power, and it makes Thai leaders change their minds, which is why Chinese investors can transform Thai temples to a Chinese style.

Finally, it is difficult to maintain Thai art in the Thai temple under globalization and capitalism. If the Thai government is not concern with Thai art, Thai culture, and Thai traditions outside Thailand, how will Thai art and culture in Malaysia stay alive?

\section{Recommendations}

1) The next study should focus on the use of temple spaces as a commercial religious space, and study the negotiation of identity and meaning in the temple between Siamese people and non-Siamese people.

2) The state should distribute more funds for Thai temples to maintain their beauty and identity. This study found that the Siamese population allowed the Chinese to manage the temple's activities because of the lack of support from state agencies, especially in Muslim states.

\section{Reference}

Alwi, E. (2010). Cross Religious and Social Interaction: A Case Study of Muslim and Buddhists in Kampung Tendong, Pasir Mas, Kelanton. Asian Social Science, 7(8), 112-122.

Bachok. (2013). Retrieved June 13, 2014, from http://www.reference.com/brown/wiki/Bochok

Beng, T. (1982). Peranakan Chinese in Northeat Kelantan with special reference to Chinese. Religion Journal of the Malaysia Branch of Royal Asiatic Society, 55(1). Retrieved May 24, 2014, from http://www.jstor.org/discover/10.2307/41492910?uid

Blackburn, A. (2012). Religion and Legitimacy: Buddhism and Formation of a Transnation Identity. Asia Research Institute, NUS and Cornell University. Retrieved June 29, 2012, from http://www.ari.nus.edu.sg/ event_categorydetails.asp?

Boas, F. (1966). Race, Language and Culture. New York: Macmillan.

Chantaro, R. (2011). Way of Malaysian-thai life. Balai: Notebooks.

Foucault, M. (2007). Space Knowledge and Power. England: Aldershot.

Funsion, J. (2010). Malaysia and Thailand's Southern Conflict: Reconciling Security and Ethnicity. Comtemporary Southeast Asia, 32(2), 234-357. Retrieved September 10, 2012, from http//ehisEbscohost.com/ehost/pdfviewer/pdfviewer? http://dx.doi.org/10.1355/cs32-2e 
Horstmann, A. (2004). Deconstrucion Citizenship from the Border. In A. Horstmann, \& R. Vadley (Eds.), Centering: The Magin: Agency and Narrative in Southeast Asian. New York: Berghahn Books.

Isa, B. (2009). Multiculturalism in Art Education: A Malaysia Perspective. Retrieved June 13, 2012, from http://www.unesco.org/culture/en/file/29700/1137 isa_badrul.pdf

Ismail, M. (1994). Survival Strategies of Siamese Buddhist Temple in Malay Muslim State Kelantan Malaysia. In International Conference on Buddhist Societies in Stability and Crisis (July 28-30, pp. 35-48). The International Center for Ethnic Studies, Srilanka and Thai Studies Institute, chulalongkorn University, (Thailand).

Johnson, I. (2011). Size matters: history, marginality, and the politics of building big in a small community. Journal of the Royal Anthropological Institute, 17, 116-134. http://dx.doi.org/10.1111/j.14679655.2010.01672.x

Kang, L., \& Feng, M. A. (2013). Historical Survey on Modernization of Chinese Culture. Asian Social Science, 9(4), 129-133. http://dx.doi.org/10.5539/ass.v9n4p129

Kataoka, T. (2012). Religion as Non-religion: the Place of Chinese temples in Phuket, Southern Thailand. Southeast Asian Studies, 1(3), 461-485.

Khin, B., \& Huat, O. (2005). Buddhist and Chinese Religions. In M. Hassan, \& G. Basri (Eds.), The Encyclopedia of Malaysia: Religions and Beliefs (pp. 60-82). Kuala Lumper: Archipelago.

Knapp, R. (2010). Chinese Houses of Southeast Asia. Singapore: Tuttle Publishing.

Mason, C. (2009). Policy and The Acculturation of The Ethnic Chinese in Malaysia. California: University of Southern.

Muhamat, R. (2012). The History of Ethnic Relationship in Malaysia. Advance Tin Natural and Applied Science, $6(4), 504-510$.

Sarimah, O. (2004). Siam in Culture: Malaysia spirit. Malaysia Business, (16), June.

Seong, T. (2008). In M. Montesano, \& P. Jory (Eds.), Chinese-Malay-Thai Interaction and the Making of Kelanton Peranakan Chinese Ethnicity (pp. 214-230). Thai South and Malay North. Singapore: NUS Press.

Srisuwan, D. (2011). Way of Malaysian-Thai Life. Balai: Notebooks.

Sthapitanonda, N., \& Mertens, B. (2005). Architecture of Thailand. Bangkok: Asia Books.

Tepsing, P. (2011). The Hybrid Style of Art in Thai Temple in the Malayan Penninsula: A Case Study of The Wat Chaiamangalaram in Penang Malaysia. The Journal of the Thai khadi Research Institute, 8(2), 84-105.

Thepsirin, N. (2011). Way of Malaysian-Thai Life. Balai: Notebooks.

\section{Copyrights}

Copyright for this article is retained by the author(s), with first publication rights granted to the journal.

This is an open-access article distributed under the terms and conditions of the Creative Commons Attribution license (http://creativecommons.org/licenses/by/3.0/). 